\title{
Philosophy of a Surname: Ukrainian Context ${ }^{[*]}$
}

\section{Soyadı Felsefesi: Ukrayna Bağlamında}

\author{
SVITLANA KHYRIPKO (D \\ Borys Grinchenko Kyiv University \\ GANNA IATSENKO \\ National Shipbuilding University
}

Received: 23.09.2019 | Accepted: 18.10.2019

\begin{abstract}
The article is devoted to an issue of surnames' phenomenon in the scientific field of Ukrainian anthroponomics. The semantic and philosophical contexts of the surnames' creation are highlighted; a Muslim trace in Ukrainian surnames is followed. The surnames are considered from a symbolic side, moreover, their origins and the ways of transformation are studied. The heritage surnames' value is mentioned in the light of their consideration as an integral part of the national culture and worldview. The work aims to provide the general systematization of patronyms (the father's names or surnames), determine and highlight the spiritual peculiarities in the structure of the family, regional surnames. An article is the second part of an extensive study of a namegiving tradition in Ukrainian culture.
\end{abstract}

Keywords: God, the Qur'an, human knowledge, Kant, meta-epistemology, transcendental arguments.

Svitlana Khrypko

Borys Grinchenko Kyiv University, Faculty of History and Philosophy, Dep. of Philosophy 04212, Kyiv, Ukraine |s.khrypko@kubg.edu.ua

$凶$ Ganna Iatsenko

National Shipbuilding University, IEDL, Department of Philosophy and Cultural Studies 54000, Mikolayiv, Ukraine iats26or@gmail.com 


\section{Introduction}

A name is a choice, motivation, aspirations, a parents' gift. A surname is inheritance. It is a clan's sign, family's code, symbol that connects us with a world of our predecessors, with a history of our family. A name is something that is acquired "here and now"; however, a surname is a voice from eternity, a gift from the predecessors' will.

The philosophical sense as love for wisdom and knowledge of the personal genealogic tree is embedded into saving, transmitting or losing a surname.

The research problem of surnames' historical mystery and semantics has never left the scientific area as it is a crucial issue which relates to everyone. Any person wants to know a history of his family and symbolic meaning of a personal surname.

How long have the surnames existed? It is a question which does not suppose an unambiguous answer, as the word "surname" is controversial.

Still to the $19^{\text {th }}$ century the main meaning of the word "family" was "generation". The word "surname" is "a name of the family", "a title of all their members" in our modern understanding. The primary purpose of the word was to name the whole family's generation in general. After the total disappearance of big patriarchal families, the word "surname" was applied to a particular person in order to show his affiliation.

Every nation has a developmental social stage (the Ukrainians is not an exception) when a name becomes insufficient, consequently the additional affiliation should be added. The father's indication, which is occurred in the culture, is rather limited. With the development of the social and legal institutes, and the introduction of official naming norms, the problem becomes crucial.

The surnames' phenomenon is connected with the spheres of anthropology, linguistics, history, philosophy and cultural semantics. It has multi-disciplinary nature and is multi-sectoral polysemantical phenomenon. The row of Ukrainian scientists were occupied by the study of semantic bases of the modern surnames, among them are G. Buchko, P. Chucka, M. Chudash, V. Gerasimchuk, B. Grinchenko, U. Karpenko, L. Krakalia, G. Lozko, A. Nechiporenko, S. Pantsio, V. Poznanska, U. 
Redko, I. Suchomlin, V. Zajvoronok and others.

The aim of the work is to provide the general systematization of patronyms (the father's names or surnames), determine and highlight the spiritual peculiarities in the structure of the family, regional surnames. Moreover, the additional purpose is to emphasize the spiritual depths of the widows' surnames and consider the Christian influence on the culture and symbolism of the newly established surnames which presented by the Church surnames. The value vectors of the spiritual roots and peculiarities of the national mentality of Cossack's anthroponomics are to be considered. Furthermore, the modern state of the issue is presented.

\section{Methods}

Methodology of the study is based on a dialectical relationship of the following methods: a comparative-historical method is applied for historic peculiarities determination in national character of the surnames; a method of general systematization is used for groups' division of the surnames; the methods of comparative, functional and systematic analysis are involved in the process of the surnames' identification, origins' explanation and provision of historical analysis through the perspective of modern usage respectively.

\section{Results and Discussions}

The living history of Ukraine, represented by the legends and thoughts, rich on the heroic deeds, had captured a colorful row of Ukrainian surnames, holders of which were the creators of the history. The lexical content of Ukrainian surnames reflected the generous character of our predecessors who eagerly gave the numerous characteristics, nicknames to each other that were transformed into the surnames later (Gerasimchuk, \& Nechiporenko, 2002, p.32). A surname as a proper noun has endured a long period of transformation, namely, having appeared in a national language on the various historical stages of development, it has always been connected to the culture, history and ordinary life. The surnames are specific to the social groups and layers; consequently their form is derived from the particular composed stems. Primarily, each nickname and surname was determined by a particular thing and had a meaning: there was a reason for giving a particular title for a person in 
order to distinguish him from the others. As M. Chudash mentioned: the most common and widely spread ways of additional personal identification were surnames, and then other features according to a place of living, origins, background, profession and individual "street" nicknames (Chudash, 1977, p.4I). A person's nickname contained a certain meaning that was fairly obvious for the certain people. Due to I. Zelezniak only a recurrence of some names created a name-symbol that had concentrated a meaning-connection (definition) with the life environment (Zelezniak, 2005, p.76-77).

\section{Patronyms as the Surnames' Determinants}

The history of semantics of the Ukrainian surnames begins from "the fathers' names". The persons' titles according to their fathers' names, so called patronyms have been known from the ancient period of Kyivan Rus. Nevertheless, they were not identical to the modern fathers' names that represented a compulsory component of a common full official person's presentation in our country. We came across the anthrophonyms of the different successors of the lords in the written records from the period of Kyivan Rus, which could be considered as the fathers' names, for instance Igorevychi, Iziaslavychi (suffix - ych is widely used in the fathers' names in order to transform a male name into a father's name). The vivid example is a main character of the epic "The Word about Igor's Regiment" - Jaroslavna. Her real name Efrosinia is rarely known (particularly to some researchers of the ancient literature); however she is well known as Jaroslavna.

It is an assumption among the researchers that the suffixes -ych and -ovych determined a function of person's affiliation to a family. For instance, Viacheslav Jaropolchych (a son of Jaropolk). V. Gerasymchyk notes that "the history of the suffixes -ych and -ovych is not rather straightforward as it seems from the first glance. The suffixes used to be applied to determine a young animal: sokolych (a young hawe), levych (a young lion), golybych (a young pigeon). Nevertheless, in the I $6^{\text {th }}$ century the other suffixes were applied to the process of animal naming, in particular -en which substituted the old ones (e.g. myshenia - a little mouse, koshenia - a kitten). It might be according an analogy the suffixes -ych and -ovych were used for the lords' children naming: Vasilko Postyslavych, Igor Yaroslavych could be met in the chronicles. Still they had not been the fathers' names yet, but identified the definition of affiliation - "a son of", 
for instance, popovych (a son of an Orthodox priest), tsarevych (a son of a tsar). The words were frequently put before the names, and not after due to the later tradition. The forms of $-y c h$ and -ovych accepted their present meaning of the fathers' names much later" (Gerasimchuk \& Nechiporenko, 2002, p.30).

To conclude the patronymistic part of the surnames' semantics, it is sensible to highlight particular parallels with the other nations. The fathers' names are a special privilege of Slavic languages; in the other linguistic groups a father's name can be included into a surname. For instance, a lot of English and German surnames end on -zon or -son, the Scandinavian names have in their structure a suffix -sen, which means " $a$ son of". The same semantic meaning can be found in the Georgian suffix shvili, Atmenian -yan, Turkish -ogly. The same role can be performed by the prefixes, among them the Scottish Mc- (e.g. Mcfobns, McCartney), the Irish O- (O'Sullivan, O'Brien), etc.

\section{The Characteristics of Proto-Surnames}

They cannot be considered the surnames in a modern understanding. It was a certain characteristic which had a particular historical person and with which he entered into the chronicles of Kyivan Rus and obtained his place in the historical memory. The fact that some historical persons mentioned in the chronicles had only the names was indisputable: Askold, Dir, Igor, Oleg, Olga, Nestor. A father's name was added to the main first name in some cases: David Vseslavych, Igor Sviatoslavych. Some historical personalities were remembered by the second name which was accepted as a surname: Volodymyr the Great (the Glorious Sun), faroslav the Wise, Sviatopolk the Blasted, Yuriy the Long-handed (means that he united all the territories under his hand).

\section{The Family Surnames}

The most ancient surnames, which were closed in a meaning to the modern surnames, appeared in the Ukrainian ancient records in the XIV - XV centuries. In particular they were presented by the proper nouns: e.g. the lord Ivan Vasiliovych Chortoryiskyi (Ivan - a son of Vasil from a land where the devils plough a land - it can mean a very distant land), Volchko (from a wolf), Rogatynskyi (with the horns). The essential feature was that all surnames belonged to the people from the top of society: lords, dukes, land 
magnates, etc. It was clearly understandable why they became the owners of the first surnames. Property selling, inheritance, other legal operations with any possession claimed to be fixed in the appropriate documents. A single name was insufficient to conclude a deal (any mess in the deals with property was dangerous and inacceptable). Furthermore, it was convenient for the successors to have a surname which would indicate their social position and remain that they are inheritors of a particular land. The fact predominantly influenced on the appearance and anchoring the family surnames: the Ostrozskyi (derived from a wooden fortress - ostrog), Vyschnevetski (derived from Ukrainian sacral tree - a cherry tree), Gorsky (derived from the word "mountain"), Sokolynsky (derived from a word "bawk" with the connotation gorgeous, gracious), etc. The enumerated surnames belong to the famous Ukrainian noble surnames. The rest of Ukrainian population was without officially fixed surnames in the meantime. The first common official introduction of the surnames into the ordinary life was provided by the Orthodox clergy, in particular under the rule of Metropolitan of Kyiv Petro Mohyla. In I632 he obliged the local priests to keep the records of social changes, namely who was born, married or dead.

The semantic and lexical base of the folk surnames was various from a personal name - "a son of" to a name of location, background, origins, a name of profession or current occupation, or a particular individual or psychological feature. Folk fantasy was boundless in the process of surnames' creation; it was a practical embodiment of national philosophy.

The primacy had the surnames derived from names. The surnames are originated from male and female names with the help of patronymic and matronymic suffixes. The most common are -enko, -uk (-juk), they reflect a meaning "son" (Petrenko - "a son of Peter", Davydenko - "a son of David", etc.) The suffix - chuk is for the surnames' derivation from a grandfather: Ivancbuk - "a grandson of Ivan", Kateryncbuk "a grandson of Catberina”.

The wide dissemination of the proper nouns of adolescents, the young with the suffix -enko, -uk (-juk) can be illustrated by the numerous examples of appropriate derivations from an occupation, profession which are presented in a dictionary of Ukrainian language edited by B.D. Grinchenko: Bondarenko "a son of a cooper" or Bondarchuk "an apprentice of a 
cooper"; Kovalenko "a son of a blacksmith" and "a learner of a blacksmith"; Maliarenko "a son of an artist", Maliarchuk "a learner of an artist"; Pysarenko "a son of a scribe", Pysarchuk "a son of a scribe" or "a young scribe, an office worker"; Schevchenko "a son of a shoemaker" or Schevchuk "an apprentice of a shoemaker"; Tsiganenko "a son of Gypsy" and Tsiganchuk "a young Gypsy", etc. Nowadays, all enumerated names of the sons, learners and apprentices are widely spread as the individual surnames.

The ancient pagan names are also transformed into surnames: $Z$ dan (something you are waiting for), Svitozar (the light from the dawn), Vernidub (a mighty person who is able to crush the oaks), etc.

The widows' surnames belong to the group of surnames derived from the names. A mother's name is infrequently applied to a surname in Ukrainian tradition. Nevertheless, there were some exceptions when a woman remained a widow early and became a head of a family. In that case a surname was derived from her name: Chrystych (derived from a name Christina), Gannych (derived from a name Anna), Mamchyn (derived from a word "mother"), Marusiak (derived from a name Mary), Maryniak (derived from a name Mary), Motrenko (derived from a name Motria), Nastenko (derived from a name Nastia), Olenych (derived from a name Elena). The forms can be easily met in Transcarpathian region. The ironical male nicknames based on the female names are also included in this category. The reason of their appearance was in the family relations when a woman was the main breadwinner and consequently dominated over her husband: Galiy (derived from a name Gala), Chimyi (derived from a name Chimka), Paraskyi (derived from a name Paraska).

\section{The Regional Surnames}

The regional surnames are divided according to the following features:

- The surnames which identify the nationality of ancestors: Cheschko (pointed on the Czech origins), Litvin (pointed on the Lithuanian origins), Rusyn (pointed on the Russian origins), Tatarchuk (pointed on the Tatar origins), Turchyn (pointed on the Turkish origins), Venger (pointed on the Hungarian origins). The surnames with Turkish origins: Gurunchak, Kochubej, Kolchak; the surnames which pointed on the Jews who were a family's founders: 


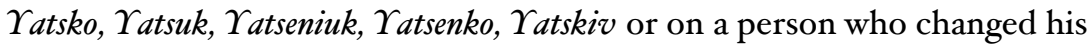
religion: Vychrystenko, Vychrastiuk;

- The surnames derived from the tribal names: Bessarab, Bojko;

- The surnames derived from the toponymical names or titles: Polischuk (derived from Polissia region), Podolskyi (derived from Podillia region), Volynets (derived from Volyn region);

- The surnames derived from a place of living in the meaning of a landscape: Bashtovyi (a person who lived near a tower), Girniak (a person lived near the mountains), Lanovyi (a person lived near the fields), Lisivyi (a person lived near a forest), Lugovyi (a person lived near a meadow), Ozernyi (a person lived near a lake), Poliovyi (a person lived near the fields), Richkivyi (a person lived near a river), Sadovyi (a person lived near the orchards), Slobodian (a person came from a sloboda, a settlement of the free people who were on the lord's service), Zakaliuznyi (a person lived in an area with deep gullies), Zamkovyi (a person lived near a fortress), etc.

\section{The Surnames Derived from Ordinary Life}

The folk and philosophical motivation of the group depicts rich social, administrative and economic life of the Ukrainians:

- The surnames derived from the range of dishes and foodstuff: Bubkyk (a pretzel), Brynza (cottage cheese), Galuschkina (a national dish from wheat dough), Kovbasiuk (sausages), Maslenko (butter), Pyrig (a pie) (Grinchenko, I909, p.210); (Zajvoronok, 2006, p.269);

- The surnames derived from the professional occupation: Chumak or Chumachenko (a person who transported the goods), Koval or Kovalenko (a blacksmith), Kozemiaka (a tanner), Krama or Kramarenko (a shop's owner), Maliar or Maliarenko (a painter), Melnik or Melnychenko (a mill's owner), Schvets or Schevchuk (a shoemaker), Stoliar or Stoliarenko (a carpenter), etc.

- The surnames derived from social division: Bidnyi (a poor man), Boyarchuk (a person belonged to a noble social class - boyare), Golota (a person belonged to a class of the poor), Kniazevskyi (a person belonged to the lords), Naimyt (a poor person who was employed to the underpaid work), Panych (a rich person belonged to the high society), etc.

- The surnames derived from administrative positions: Gubernachuk (occupied a governor's position), Dvoknychuk (occupied a position of a yard keeper), Mostovenko (occupied a position of bridges' builder), Starostenko (occupied a 
position of a village's Oldman), Voznuk (occupied a position of a carrier), etc.

- The surnames derived from the military sphere: Chorunzyi (a military position derived from a flag keeper), Getman (Commander-in-Chief), Puschkar (a guns'keeper), Soldatenko (a soldier), Sotnyk or Sotnychenko (a military commander of a troop consisted from a bundred people), Otaman (a military commander), Zaporozets (the soldiers from Zaporozskaya Sich), etc.

- The surnames derived from the involvement into a life of the Orthodox Church: Diak or Diachenko (a deacon), Ponomar or Ponomarenk (a sexton), Popovich (a folk name of a priest), Spivak (a singer in a Church Choir), etc. The surnames of the Orthodox Church clergy should be mentioned separately which were given after the graduation from seminaries and Kyiv-Mohyla Academy in the I8th - I9th century. For instance, Rozdestvenskyi (reminded about Christ's birth), Spaskyi (reminded that Christ is a Savior), Voznesenskyi (reminded about the rapture of fesus Christ), etc. The above-mentioned surnames aimed to distinguish the clergy from the secular people.

The poly-semantic meaning and multiplied polarity of surnames' history was often a reason for misunderstanding. Till the $I 7^{\text {th }}$ century there was a situation when an official person's identification was simultaneously based on official and folk traditions. The usage of proper nouns was not restricted even in the official documents, and was indicated by instable forms and ways of their application. A vivid illustration was presented by Ivan Franko in the article "Introduction to Ukrainian onomastics". In I667 a Moscow courtier Kikin considered a complaint in Poltava; however he was not able to solve the problem as there were no Cossacks' surnames in a regimental register which were mentioned in the complaint. According to a courtier's request a Colonel Vytiazenko answered: "The Cossacks have different surnames owing to a tradition as the people give various nicknames: for instance, one person can bave three or four surnames - according to a father's name, to a father-in-law name, to a mother-in-law name, to a woman's name. Consequently, the same people are registered in a common list according to one surname and in our Cossack's list according to other".

\section{The Cossacks' Surnames}

It is a separate creative and humorous page of Ukrainian anthroponomics. The lists and other documents from Zaporozskyi's archive give 
an opportunity to follow a process of surnames' creation, study the sources and conditions of their appearance. During the process of their creation the Cossacks highlighted creativity, humor and invention. The surnames depict the history, demography, ethnography, economy, social and national relations, ordinary life and traditions of the Ukrainians. We can observe the internationalism of Zaporozskaya Sich where the representatives of various nations were presented in practice. A lot of Cossacks obtained the surnames: Gurzui or Gurzyi (derived from the Georgians' identification in $8^{\text {th }}$ century), Gutsul (derived from a name of Carpathian inhabitants), Liach (derived from the Polish origins which can have a holder), Lytvyn (derived from the traces of Lithuanian origins), Moldovyn (derived from the traces of Moldovan origins), Moscovyt (derived from the traces of Russian origins), Polyliach (derived from the traces of Polish origins), Serbii (derived from the traces of Serbian origins), Tsyganko (derived from the traces of Gypsy origins), Turchyn (derived from the traces of Turkish origins), Ugorets (derived from the traces of Hungarian origins), Virmenko (derived from the traces of Armenian origins), etc.

The most flamboyant is a group of Ukrainian surnames which contains the features of appearance, traits of character or behavior of the Cossacks. The most significant word is used to determine a person: Bilan (fair-haired), Boroda (with prominent beard), Bystrytskyi (someone who is fast), Chornyi (dark-haired), Chub (with a prominent tuft), Cherevatyi (who is overweight), Chmara (who is always in a bad temper), Golovatyi or Golovko (with big head), Gorbonis (with a crooked nose), Guba (with big prominent lips), Kosyi or Kosach (cross-eyed), Nemylostyvyi or Neschadnyi (rutbless), Nis, Nosan or Nosenko (with big prominent nose), Riabyi (with freckles), Schram (with a scar), Slipyi (blind), Suchyi or Smorchok (extremely anorectic person in negative meaning), Usatyi (with mustache), Velykyi (tall person), Zub or Zubatyi (with big prominent teeth), etc.

The surnames can be conditionally divided on the following groups:

- height or size: Dovgan (tall), Kutsyk or Malyschko (small), Puzan (with prominent belly, etc.;

- parts of body: Bezuchko (with extremely small ears), Chornookyi (darkeyed), Golovatyi (with big head), Kryvonis (with crooked nose), etc.;

- physical peculiarities: Chromets (lamed), Glushko (deaf), Gorban (with a 
bump), Kosogliad (cross-eyed), Slipak (blind), etc.;

- psychological features: Krykun (loud), Movchun (quiet), Myrnyi (calm), Prychepa (annoying person), Repetylo (repeats information all the time), Smuta or Zurylo (moody), Zadyraka (scrappy); etc. (Zajvoronok, 2007, p.I96);

- the surnames based on onomatopoetic semantics: Chvak (derived from the word slurping), Goida or Gots, (derived from a process of swinging), Krut (derived from a process of spinning), Kukuriko (derived from the exclamation "cock-a-doodle-do"), Zivaka (derived from yawning), etc.;

- the surnames depicted the clothes' peculiarities: Bezpoiasko (without a belt), Kryvoschapka (with a bad hat), Schtanko (with short trousers), Siroschtan (with grey trousers), etc.;

- the surnames derived from the mocking street nicknames: Bezborodko (without beard), Netudychata (a person with odd behavior), Nepyipyvo (a dedicated beer-drinker), Masloid (a dedicated butter-eater), Skorobrech or Chornobai (a prominent liar), Varyvoda (an annoying and troublesome person), etc.;

- The music and humor of an epoch was embodied into the following layer of Cossack's surnames which were unique for Ukrainian and world culture. A reckless and open spirit of Cossack's community generated a row of funny surnames distinguished Ukrainian national anthroponomics. The whole Cossack's mentality was in the surnames: Golyboroda (with excessed facial hair), Guliajden (lazy), Nagnybida (indefatigable optimist), Neizmak or Neizborsch (picky with food), Perebyinis (a bully), Pokyncherevko (likes to eat), Zagubyvatko (extremely absent-minded), Zaderychvist (boastful), etc.;

A great amount of the Ukrainian surnames was created during the period of Zaporozskaya Sich existence. The necessity of official registration of a significant number of people historically appeared there. According to the traditions of Zaporozskaya Sich, a newcomer should choose an absolutely new surname that was written to an official military register. The Cossack's community had a unique opportunity to show their humor during a procedure of surname's choosing. A ritual of newcomer's acceptance to the troops was described by Dmitro Yavornytskyi in the work "History of Cossacks from Zaporozya": "Primarily, a newcomer was written to one of the $3^{\text {th }}$ kurens (official military administrative division) according to his personal choice and where his surname was changed into a new one 
which characterized his appearance or traits of character for creation a unique identification mark of a person. The second reason of surnames' change was to bide the past of Sich newcomers. Frequently, according to an enquiry of the Russian or Polish governments about presence of Ivanov or Vojnovych among the Cossacks, the official Sich responded that there were no such persons. However, Zaderychvist or Zagubykoleso came to the Sich in the meantime..."

\section{Conclusion}

The motivational reason of flamboyant and in some cases grotesque nature of the Ukrainian surnames should be traced in the national history from Cossack's period. The analyzed surnames additionally proof bright, socially colored and humorous character of the Ukrainians.

The surnames are an embodiment of mentality, national character, history with rise and fall, as they contain all the past actions. A detailed study of the most common surnames provides a basis for the further predictions of national development. Consequently, personal names have a particular code of time reflection and a place of their appearance. They can be particular milestones in the process of cultural, philosophic, historical study, as they faultlessly depict all historical and cultural transformations.

\section{References}

Buchko, G. (1992). The Surnames of Boykovschina and Pagan beliefs of the Western Slavs: Onomastics of Ukraine of the first century of our era, $183-186$.

Chuchka, P. (20II). The Slavic Proper Nouns: Historical and Etymological Dictionary. Uzgorod: Lira.

Chudash, M. (1977). From the History of Ukrainian Anthroponomics. Kyiv: Scientific Thought.

Dictionary of Ukrainian Language ed. by B. Grinchenko (1907-1909). Kyiv.

Franko, I. (1982). The Reasons of Ukrainian Onomastics. 36 vols. Kyiv: Scientific Thought.

Garasim, Y. (2009). The Description of Ukrainian Folklore History. Kyiv: Knowledge.

Gerasimchuk, V. \& Nechiporenko, A. (2002). Anthroponims: History and Modern Times. Kamianetz-Podolski: Knowledge.

Gorpynych, V., Kornienko, I. (2006). Anthroponymics of Pryporizia and the Neighbor 
Regions of Ukraine. Dnipropetrovk - Mykolaev: Illion.

Khrypko, S. (2018). The Valued Focus of $a$ Widow and an Orphan Statuses and Scale of Protection in the Old and New Testament tradition. Skhid, 3 (I55), 5I-56.

Khrypko, S. \& Iatsenko, G. (2019). Philosophy of a Name: Ukrainian Context. Beytulhikme An International Journal of Philosophy, 9 (2), 437-45I.

Lozko, G. (20II). Native Names. Slavic Names' Collection. Ternopol: Mandrivets.

Masenko, L. (1990). The Ukrainian Names and Surnames. Kyiv: The Knowledge.

Ostasch, P. (1989). The Types of Names according to the Origins. The Registers of all Zaporizia Troops and Language-Territorial context in I649. Kyiv: Scientific Thought.

Redko, Y. (1966). Contemporary Ukrainian Nicknames. Kyiv: Scientific Thought.

Savitska, S. \& Savitski, O. (2012). The Names Collection: Slavic Names. Ternopol: Mandrivets.

Skripnik, L. \& Dziatkivska, N. (1996). The Proper Names. Kyiv: Scientific Thought.

Suchomlin, I. (1970). Ukrainian Surnames as Proper Names. Speech and Onomastics of Naddniprianschina, $\mathrm{I2}, 30-58$.

Voropaj, O. (1993). The Traditions of our Nation: Ethnographical Description. Kyiv: Oberig.

Yavornytskyi, D. (1990). The History of the Cossacks from Zaporizia. Lviv: The World.

Zajvoronok, V. (2006). The Signs of Ukrainian Ethnoculture. Kyiv: Dovira.

Zajvoronok, V. (2007). Ukrainian Ethno Linguistics. Kyiv: Dovira.

Zelezniak, I. (2005). The Worldview's Code of Slavs Anthroponymic Lexics. Kyiv.

Öz: Makale, Ukrayna antroponomisinin bilim alanındaki soyadı fenomeni konusuna ayrılmıștır. Soyadı olușturma ișleminin semantik ve felsefi bağlamları vurgulanır; Bunu Ukrayna soyadlarında Müslüman izleri takip ediyor. Soyadı sembolik bir taraftan ele alınır, dahası, kökenleri ve dönüșüm yolları incelenir. Miras soyadlarının değeri, onların düșünceleri ıșığında, ulusal kültür ve dünya görüșünün ayrılmaz bir parçası olarak belirtilmektedir. Çalıșma, aile adlarının (babanın adları ya da soyadlarının) genel sistematikleștirilmesini sağlamayı, aile- 
nin yapısındaki manevi özellikleri, bölgesel soyadlarını belirlemeyi ve vurgulamayı amaçlamaktadır. Makale, Ukrayna kültüründe adlandırma geleneğinin kapsamlı bir çalıșmasının ikinci kısmıdır.

Anahtar Kelimeler: Soyadı, özel ad, antroponomi, ulusal manevi gelenek, etnik kültür.

${ }^{[*]}$ The article is the second part of an extensive study of a name-giving tradition in Ukrainian culture. The first part about Ukrainian names was published in: Philosophy of a Name: Ukrainian Context. Beytulbikme An International fournal of Philosophy, 9 (2), (2019), 437-45I. 